\title{
Clinical and molecular studies in a unique family with autosomal dominant limb-girdle muscular dystrophy and Paget disease of bone
}

\author{
Virginia E. Kimonis, $M D, M R C P^{1}$, Margaret J. Kovach, $P h D^{1}$, Brook Waggoner, BS $S^{1}$, Suzanne Leal, $P h D^{2}$,
} Ambar Salam, $B S^{2}$, Lisa Rimer, $M S^{3}$, Katherine Davis ${ }^{1}$, Romesh Khardori, $M D^{4}$, and David Gelber, $M D^{5}$

\begin{abstract}
Purpose: To characterize the clinical features and perform linkage analysis of candidate loci in a large Illinois family with autosomal dominant limb-girdle muscular dystrophy (LGMD) and Paget disease of bone (PDB). Methods: The family includes 11 affected individuals $(8 \mathrm{M}, 3 \mathrm{~F}$ ). Clinical, biochemical and radiologic evaluations were performed to delineate clinical features of the disorder. Linkage analysis with polymorphic markers was performed for previously identified LGMD, PDB and cardiomyopathy loci. Results: Onset of PDB is early, at a mean age of 35 y, with classic distribution involving the spine, pelvis, and skull. Muscle weakness and atrophy is progressive with mildly elevated to normal creatine phosphokinase levels. Muscle biopsy in the oldest male revealed vacuolated fibers, however, in others revealed nonspecific myopathy. Affected individuals die from progressive muscle weakness, and respiratory and cardiac failure in their 40s-60s. Linkage analysis excluded autosomal dominant and recessive LGMD, PDB, and cardiomyopathy loci. Conclusion: Autosomal dominant LGMD associated with PDB is an unusual disorder. Linkage analysis indicates a unique locus in this family. Genetics in Medicine, 2000:2(4):
\end{abstract} 232-241.

Key Words: Limb-girdle muscular dystrophy, Paget disease of bone, autosomal dominant, vacuolar myopathy

We describe a family with autosomal dominant limb-girdle muscular dystrophy (LGMD) with the associated finding of early onset Paget disease of bone (PDB) and cardiomyopathy in a few individuals. Three similar associations of neuromuscular disease and Paget disease of bone have been previously reported. Familial PDB in association with dystrophia myotonica was reported in one family by Caughey et al.' (MIM $\left.16,0900^{2}\right) . \mathrm{McBride}^{3}$ found an association of PDB and a limb girdle type of muscular dystrophy in four of six siblings and Tucker et al. ${ }^{4}$ identified a family with autosomal dominant amyotrophic lateral sclerosis (ALS, MIM 10,5400²) and PDB.

Characterized by progressive proximal muscle dystrophy and weakness particularly of the shoulder and pelvic girdle with relative sparing of the other muscle groups, limb-girdle muscular dystrophies are a clinically and genetically heterogeneous group of neuromuscular diseases. At least 4 autosomal dominant and 8 autosomal recessive forms of LGMD have been reported. LGMD1A, located on chromosome 5q22-q31,

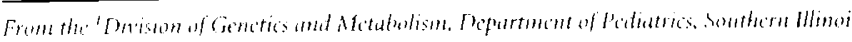

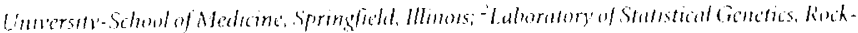

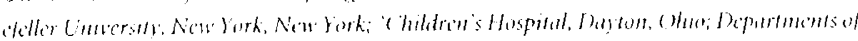

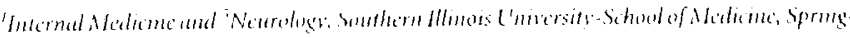
fich, Illmois

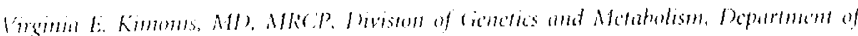

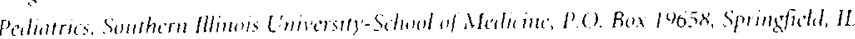
$02791-96,58$

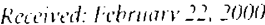

Accopted: Mar' 22, 20130.
}

is caused by a mutation in myotilin, a sarcomeric structural protein. ${ }^{5-7}$ LGMD1C, caused by mutations in the muscle specific protein, caveolin-3, is located on chromosome $3 \mathrm{p} 25 .^{8-9}$ The genes for LGMD1B (1q11-q21), ${ }^{10}$ LGMD1D (7q), ${ }^{11}$ and Edstrom myopathy, a related autosomal dominant myopathy that maps to $2 \mathrm{q} 24-\mathrm{q} 31,12$ are yet to be identified.

The genes for eight of the recessive forms of LGMD have been identified, the majority of which encode for components of the dystrophin-sarcoglycan complex (Table 1). None of these loci have been implicated in autosomal dominant neuromuscular or bone disease.

Autosomal dominant limb-girdle muscular dystrophy is associated with cardiomyopathy in LGMD1B and also in another family with dilated cardiomyopathy with conduction defect (CDCD3) located on chromosome $6 \mathrm{q} 23 .{ }^{13}$ The loci for cardiomyopathy were therefore considered candidates for the disease in our family.

Paget disease of bone is characterized by an increase in bone remodeling and hypertrophy leading to abnormal bone structure, bone pain, and deformity. ${ }^{14}$ McKusick ${ }^{15}$ reviewed 37 families with familial Paget disease of bone (PDB). Only one family exhibited male-to-male transmission suggesting the rarity of autosomal dominant families. Subsequently, two genetic loci have been linked to autosomal dominant PDB. The first to be identified, PDB1, was obtained with the HLA locus on chromosome $6 \mathrm{p} .{ }^{16} \mathrm{PDB} 2$ was assigned to chromosome 18 p21-2217 in a large Northern Irish family with PDB, and recently mutations in the gene TNFRSF11A were found in as- 
Table 1

Clinical and genetic heterogeneity of limb-girdle muscular dystrophy and Paget disease of bone

\begin{tabular}{|c|c|c|c|c|c|}
\hline Type & Reference & Inheritance & $\begin{array}{l}\text { Chromosomal } \\
\text { locus }\end{array}$ & $\begin{array}{l}\text { Protein } \\
\text { Defect }\end{array}$ & Clinical Features \\
\hline LGMDIA & 5,6 & Dominant & $5 q 22.3-q 31.3$ & Myotilin & $\begin{array}{l}\text { Onset } 18-35 \text { y, progressive muscle disease, mildly elevated } \mathrm{CPK} \text {, tight Achilles } \\
\text { tendon, distinctive dysarthric speech, anticipation }\end{array}$ \\
\hline LGMDIB & 10 & Dominant & $1 q 11-q 21$ & Unknown & $\begin{array}{l}\text { Onset muscle weakness }<20 \text { y in } 50 \%, C P K \text { normal, mild muscular dystrophy } \\
\text { on EMG and muscle biopsy. Death from cardiomyopathy }\end{array}$ \\
\hline LGMDIC & 8,9 & Dominant & $3 \mathrm{p} 25$ & Caveolin 3 & $\begin{array}{l}\text { Calf hypertrophy, mild to moderate weakness, CPK is } 4-25 \times \text { normal, rapid } \\
\text { progression in one family }\end{array}$ \\
\hline LGMDID & 11 & Dominant & $7 \mathrm{q}$ & Unknown & No related cardiomyopathy, I family had early onset muscle weakness \\
\hline $\begin{array}{l}\text { Edstrom } \\
\text { Myopathy }\end{array}$ & 12 & Dominant & $2 q 24-q 31$ & Unknown & $\begin{array}{l}\text { Normal to mild elevation of } \mathrm{CPK} \text {, myopathic changes on EMG, no necrosis or } \\
\text { fibrosis on muscle biopsy }\end{array}$ \\
\hline LGMD2A & 34,35 & Recessive & $15 q 15.1-q 21.1$ & Calpain & $\begin{array}{l}\text { Majority onset } 8-15 \text { y, calf hypertrophy, Achilles tendon contractures, } \\
\text { respiratory complications severe, no cardiac involvement }\end{array}$ \\
\hline LGMD2B & 36 & Recessive & $2 \mathrm{p}^{13}-\mathrm{pl} 16$ & $\begin{array}{l}\text { Dysferlin/ } \\
\text { DYSF }\end{array}$ & $\begin{array}{l}2 \text { families. Onset in late teens, with slow progression, CPK is } 25-56 \times \text { normal, } \\
\text { EMG myopathy, muscle biopsy necrotising myopathy }\end{array}$ \\
\hline LGMD2C & 37 & Recessive & $13 q 12$ & $\begin{array}{l}\text { Gamma } \\
\text { sarcoglycan }\end{array}$ & $\begin{array}{l}\text { Onset before } 5 \mathrm{y} \text {, calf shows muscle pseudohypertrophy, CPK elevated early, } \\
\text { lumbar lordosis. Death typically before } 20 \mathrm{y}\end{array}$ \\
\hline LGMD2D & 38 & Recessive & $17 \mathrm{q} 21$ & $\begin{array}{l}\text { Alpha } \\
\text { sarcoglycan }\end{array}$ & $\begin{array}{l}\text { Typical childhood onset, calf hypertrophy, Achilles tendon contractures, } \\
\text { elevation in CPK, respiratory impairment }\end{array}$ \\
\hline LGMD2E & 39 & Recessive & $4 \mathrm{q} 12$ & $\begin{array}{l}\text { Beta } \\
\text { sarcoglycan }\end{array}$ & Progressive weakness, elevated CPK, dystrophic changes in muscle biopsy \\
\hline LGMD2F & 40,41 & Recessive & $5 q 33-q 34$ & $\begin{array}{l}\text { Delta } \\
\text { sarcoglycan }\end{array}$ & $\begin{array}{l}\text { Onset } 2-7 y \text {, confinement to a wheelchair at } 11-16 y \text {, death from } 9-19 y \text {, } \\
\text { serum CPK elevated } 10-50 \times \text { normal }\end{array}$ \\
\hline LGMD2G & 42,43 & Recessive & $17 q 11-12$ & Telethonin & $\begin{array}{l}\text { Mean age onset } 12.5 \text { y, difficulty to walking on heels, absent tendon reflexes, } \\
\text { foot drop, no cardiac disease, CPK } 3-17 \times \text { normal, muscle biopsy showed } \\
\text { myopathy and } 1 \text { rimmed vacuole/fiber }\end{array}$ \\
\hline LGMD2H & 44 & Recessive & $9 q 31-q 33$ & Unknown & $\begin{array}{l}\text { Onset between } 8-27 \text { y, CPK elevated } 2-30 \times \text { normal, facial muscles involved, } \\
\text { usually ambulant until late in life }\end{array}$ \\
\hline PDB1 & 16 & Dominant & $6 \mathrm{p}$ & Unknown & Classic distribution of Paget in 29 individuals in 3 families \\
\hline PDB2 & 17,18 & Dominant & $18 \mathrm{q} 21-22$ & RANK & $\begin{array}{l}\text { Alkaline phosphotase } 25-2000 \mathrm{U} / \mathrm{L} \text {, classic distribution of Paget disease in } 8 \\
\text { affected individuals in an Irish family }\end{array}$ \\
\hline
\end{tabular}

sociation. ${ }^{18}$ TNFRSF11A encodes for a receptor activator of nuclear factor- $\kappa \mathrm{B}$ (RANK), which is essential for osteoclast formation. In addition to PDB1 and PDB2, there is evidence for further genetic heterogeneity in Paget disease of bone. ${ }^{19}$

Linkage analysis with genetic markers for LGMD, cardiomyopathy and PDB excluded all dominant and recessive forms of LGMD as well as 6 loci for dominant dilated cardiomyopathy and 2 loci reported for dominant Paget disease of the bone (Table 2). These studies indicate that a unique locus exists for autosomal dominant LGMD in association with Paget disease of bone.

\section{MATERIALS AND METHODS}

\section{Clinical studies}

Clinical studies were approved by the Springfield Committee for Research Involving Human Subjects, and consent was obtained from each subject prior to participation. Several members of this six-generation family (Fig. 1) were examined for the presentation of LGMD and PDB through clinical, bio- chemical, and radiologic studies. Diagnosis for LGMD was based on physical examination for proximal muscle weakness and laboratory test results of creatine phosphokinase (CPK) levels in the blood. Skeletal surveys including the skull, spine, hips, long bones, and hands and feet were performed to evaluate Paget disease in family members. X-rays were read by a radiologist without prior knowledge of the individual's affected status. Pyridinoline/deoxypyridinoline collagen crosslinking metabolites in urine samples and quantitation of bonespecific alkaline phosphatase and osteocalcin levels in blood were performed by Quest Diagnostics (San Juan Capistrano, CA) and Emory University (Atlanta, GA), respectively.

\section{Cytogenetic analysis}

High-resolution karyotype analysis at $800-850$ band resolution performed on case 9 was normal excluding a deletion or other rearrangements as the cause of this unusual disorder (Genzyme Genetics, Santa Fe, NM, and Washington University, St. Louis, MO). 
Table 2

Two point LOD score analysis reflecting linkage between LGMD/PDB disease and known disease loci*

\begin{tabular}{|c|c|c|c|c|c|c|c|c|c|c|c|c|c|c|}
\hline Marker & MIM Number ${ }^{2}$ & Locus & Chromosome & 0.00 & 0.01 & 0.02 & 0.03 & 0.04 & 0.05 & 0.10 & 0.20 & 0.30 & 0.40 & Exclusion \\
\hline DSS479 & 159000 & LGMDIA & $5 q 22.3-q 31.1$ & -9.96 & -4.29 & -3.55 & -3.09 & -2.76 & -2.49 & -1.63 & -0.77 & -0.33 & -0.09 & $7.05 \mathrm{cM}$ \\
\hline D5S500 & 159000 & LGMDIA & $5 q 22.3-q 31.1$ & -6.47 & -3.30 & -2.68 & -2.30 & -2.03 & -1.82 & -1.14 & -0.51 & -0.23 & -0.08 & $4.01 \mathrm{cM}$ \\
\hline D1S305 & 159001 & LGMDIB/CDCDI & $1 q 11-q 21$ & -9.72 & -4.29 & -3.49 & -2.99 & -2.63 & -2.35 & -1.46 & -0.62 & -0.24 & -0.06 & $6.03 \mathrm{cM}$ \\
\hline APOA2 & 159001 & LGMDIB/CDCDI & lq11-q21 & -14.04 & -7.11 & -5.71 & -4.88 & -4.28 & -3.82 & -2.42 & -1.11 & -0.46 & -0.12 & $12.24 \mathrm{cM}$ \\
\hline D3S1263 & 601253 & LGMDIC/CDCD2 & $3 p 25$ & -11.05 & -5.30 & -4.39 & -3.80 & -3.36 & -3.01 & -1.88 & -0.82 & -0.33 & -0.09 & $9.10 \mathrm{cM}$ \\
\hline D7S550 & 603511 & LGMDID & $7 q$ & -7.74 & -4.28 & -3.56 & -3.12 & -2.80 & -2.54 & -1.74 & -0.91 & -0.43 & -0.15 & $7.05 \mathrm{cM}$ \\
\hline D2S138 & 603689 & Edström's myopathy & $2 q 24-q 31$ & -6.75 & -0.27 & 0.11 & 0.33 & 0.48 & 0.59 & 0.83 & 0.79 & 0.50 & 0.17 & On marker \\
\hline D2S1245 & 603689 & Edström's myopathy & $2 q 24-q 31$ & -3.58 & -0.63 & -0.24 & -0.01 & 0.15 & 0.26 & 0.53 & 0.51 & 0.26 & 0.06 & On marker \\
\hline D21S1255 & 105400 & ALSI & $21 \mathrm{lq} 22.1$ & -6.69 & -3.04 & -2.48 & -2.10 & -1.82 & -1.59 & -0.87 & -0.28 & -0.09 & -0.04 & $3.00 \mathrm{cM}$ \\
\hline D15S778 & 253600 & LGMD2A & $15 q 15.1-q 21.1$ & -2.70 & -1.17 & 0.87 & -0.68 & -0.55 & -0.44 & -0.09 & 0.17 & 0.18 & 0.08 & On marker \\
\hline D2S2113 & 253601 & LGMD2B & 2p13-pl6 & -16.53 & -5.12 & -3.93 & -3.23 & -2.75 & -2.38 & -1.28 & -0.39 & -0.07 & 0.00 & $6.03 \mathrm{cM}$ \\
\hline D13S115 & 253700 & LGMD2C & $13 q 12$ & -6.55 & -3.30 & -2.71 & -2.34 & -2.06 & -1.84 & -1.13 & -0.48 & -0.18 & -0.05 & $4.00 \mathrm{cM}$ \\
\hline $\mathrm{ADL}$ & 600119 & LGMD2D & $17 \mathrm{q} 21$ & -5.73 & -2.74 & -2.18 & -1.80 & -1.51 & -1.28 & -0.55 & 0.04 & 0.16 & 0.09 & $2.00 \mathrm{cM}$ \\
\hline D4S2690 & 604286 & LGMD2E & 4912 & -4.24 & -1.05 & -0.72 & -0.51 & -0.36 & -0.25 & 0.09 & 0.28 & 0.23 & 0.08 & On marker \\
\hline D5S470 & 601287 & LGMD2F & $5 q 33-q 34$ & -12.58 & -4.49 & -3.73 & -3.26 & -2.90 & -2.62 & -1.72 & -0.83 & -0.35 & -0.10 & $8.07 \mathrm{cM}$ \\
\hline DI7S1818 & 601954 & LGMD2G & $17 q 11-q 12$ & -8.93 & -3.42 & -2.82 & -2.48 & -2.23 & -2.04 & -1.42 & -0.70 & -0.27 & -0.06 & $5.02 \mathrm{cM}$ \\
\hline D17S250 & 601954 & LGMD2G & $17 q 11-q 12$ & -10.97 & -7.50 & -6.23 & -5.42 & -4.82 & -4.34 & -2.80 & -1.31 & -0.57 & -0.17 & $14.38 \mathrm{cM}$ \\
\hline D9S302 & 254110 & LGMD2H & $9 q 31-q 33$ & -11.67 & -4.37 & -3.54 & -3.02 & -2.65 & -2.36 & -1.52 & -0.85 & -0.52 & -0.23 & $6.03 \mathrm{cM}$ \\
\hline D6S105 & 167250 & PDBl & $6 p 21.2$ & -9.93 & -4.31 & -3.63 & -3.19 & -2.86 & -2.59 & -1.67 & -0.72 & -0.26 & -0.05 & $7.05 \mathrm{cM}$ \\
\hline D18S60 & 602080 & PDB2 & $18 \mathrm{q} 21-\mathrm{q} 22$ & -4.76 & -2.04 & -1.71 & -1.52 & -1.37 & -1.26 & -0.89 & -0.47 & -0.21 & -0.05 & $1.00 \mathrm{cM}$ \\
\hline D18S42 & 602080 & PDB2 & $18 \mathrm{q} 21-\mathrm{q} 22$ & -9.06 & -4.72 & -3.94 & -3.44 & -3.06 & -2.76 & -1.77 & -0.79 & -0.31 & -0.07 & $8.07 \mathrm{cM}$ \\
\hline D9S152 & 600884 & CMDIB & $9 q 13-q 22$ & -7.70 & -1.53 & -1.19 & -0.99 & -0.84 & -0.72 & -0.35 & -0.03 & 0.06 & 0.05 & On marker \\
\hline D9S153 & 600884 & CMDIB & $9 q 13-q 22$ & -7.88 & -1.42 & -1.07 & -0.87 & -0.72 & -0.61 & -0.28 & -0.05 & -0.01 & -0.02 & On marker \\
\hline D10S201 & 601493 & CMDIC & $10 \mathrm{q} 21-\mathrm{q} 23$ & -13.09 & -4.98 & -4.12 & -3.57 & -3.16 & -2.83 & -1.79 & -0.79 & -0.30 & -0.06 & $8.07 \mathrm{cM}$ \\
\hline DIS4l4 & 601493 & CMDID & $1 \mathrm{q} 32$ & -5.31 & -0.79 & -0.25 & 0.05 & 0.24 & 0.38 & 0.70 & 0.71 & 0.47 & 0.19 & On marker \\
\hline D6S262 & 602067 & $\mathrm{CMD} 1 \mathrm{~F} / \mathrm{CDCD} 3$ & $6 \mathrm{q} 23$ & -5.42 & -1.67 & -1.30 & -1.05 & -0.87 & -0.71 & -0.22 & 0.16 & 0.20 & 0.10 & On marker \\
\hline D6S1040 & 602067 & CMDIF/CDCD3 & $6 q 23$ & -5.93 & -3.06 & -2.52 & -2.16 & -1.90 & -1.69 & -1.02 & -0.42 & -0.14 & -0.03 & $3.00 \mathrm{cM}$ \\
\hline
\end{tabular}

* $\mathrm{CDCD}$, cardiomyopathy, dilated, conduction defect; $\mathrm{CMD}$, cardiomyopathy, dilated.

\section{DNA marker analysis}

Peripheral venous blood was obtained by standard venipuncture. Genomic DNA was extracted by means of the PUREGENE DNA Isolation Kit (Gentra Systems; Minneapolis, MN). In cases where blood samples could not be obtained, buccal scrapings were collected and processed using standard methods. Genotyping was performed to exclude/include linkage to known chromosome locations of the autosomal dominant and recessive forms of LGMD, dominant dilated cardiomyopathy, and PDB using microsatellite markers (Research Genetics, Inc., Huntsville, AL).

\section{Linkage analysis}

Linkage analysis was carried out on 23 members of the family ( 9 affected, 13 unaffected, and 1 unaffected spouse) with molecular markers for established loci of LGMD, Edstrom myopathy, PDB and cardiomyopathy (Table 2). The amyotrophic lateral sclerosis locus on $21 \mathrm{q}$ was also excluded in view of its association with PDB. ${ }^{4}$ The power to detect linkage with the available pedigree was evaluated by simulating a marker locus with 5 alleles of equal frequency (heterozygosity $=0.8$ ) completely linked to the disease locus (theta $=0.0$ ) utilizing the SLINK program..$^{20-21}$ The analysis was carried out under an autosomal dominant model. All individuals included in the analysis were above 20 years of age. Three age dependent liability classes were used to generate the pedigrees and to analyze them. It was assumed that there were no phenocopies and ratio of being wild type to being a disease allele carrier is as follows: $20-29$ years old (1.11:1); 30-34 years old; $(5: 1)$, and 35 years and over (50:1). Two-point linkage analysis was carried out using the MLINK program of the FASTLINK computer package. ${ }^{22}$ The marker-allele frequencies were estimated from the data by means of both observed and reconstructed genotypes of founders within the pedigrees. Linkage was considered established to a locus if a positive LOD score of 3 was obtained and was considered excluded if a LOD score of -2 was obtained. 


\section{RESULTS}

\section{Clinical studies}

Several members of this 6-generation family have been examined. The family includes several affected individuals; however, many are deceased prematurely from cardiomyopathy or other complications related to LGMD/PDB. The disorder in this family begins insidiously in the late $20 \mathrm{~s}-30$ s in many individuals with back and hip pain, in addition to weakness and atrophy of the proximal arm and leg muscles. Nerve conduction studies were normal in most individuals. EMG shows muscle denervation. Bone X-rays of the spine, pelvis, shoulder, and skull indicate coarse trabeculation, cortical thickening, and spotty sclerosis consistent with the diagnosis of PDB. The disorder progresses to wheelchair confinement, quadriparesis, bedfastness, respiratory failure, cardiac failure, and death in the 40s-60s. Two individuals have had limited benefit from intravenous pamidronate several years ago. Two individuals received calcitonin with limited benefit, and one female is receiving alendronate with clinical improvement.

The following individuals were identified as affected from previous medical evaluations and/or clinical examination performed. Clinical data of the these affected individuals are summarized in Table 3, and laboratory data including alkaline phosphatase, osteocalcin and CPK levels are summarized in Table 4.

Case 1, the proband, a 48 y old female, developed back pain at the age of $34 \mathrm{y}$. X-rays of the spine and hip, and bone scan, revealed increased uptake in the $L 2$ lumbar spine and the left ileum, suspicious for malignancy. A bone biopsy, however, revealed Paget disease and no evidence of malignancy. At age $34 \mathrm{y}$, she also noted proximal muscle weakness causing difficulty raising her arms. She had previously noticed tiredness and pain in her legs. At age $37 \mathrm{y}$, she had difficulty walking up the stairs, which she climbed by pulling herself up with her arms. She was diagnosed with LGMD at the age of $44 \mathrm{y}$. On physical examination, she had weakness of the proximal muscles of the arms and legs. There was a lumbar lordosis and her gait was wide based. The reflexes, sensation, and muscle tone in her limbs was normal. Bone specific alkaline phosphatase levels were markedly elevated.

Case 2 is a 47 y old male who admitted to a history of weakness of arms and legs and muscle pain for the previous 5 years. An examination at age $47 \mathrm{y}$ revealed minimal weakness of the proximal muscles. A subsequent muscle biopsy revealed variation in fiber size with fiber splitting, fiber nesting, and atrophic and hypertrophic fibers. The muscle was described as having mild myopathic changes. In addition, there was focal endomysial fibrosis, but no necrosis, regeneration, or degeneration of muscle fibers, features consistent with muscular dystrophy. An EMG at 45 y showed moderate fibrillation potentials, increased muscle fiber irritability, and small amplitude motor potentials, indicating a primary muscle disorder. Nerve conduction velocities (NCV) of the left upper and lower extremities were normal. All laboratory tests were within normal range and $\mathrm{x}$-rays did not show evidence of Paget disease. He had a myocardial infarct at age $42 \mathrm{y}$ and subsequently was diagnosed with cardiomyopathy.

Case 3, a 49 y old female, has a $10 \mathrm{y}$ history of back pain and occasional pain of the knees and calves. She complained of "Charlie horses" in the bottom of her feet, shoulders, and neck. Radiologic evaluation revealed sclerosis and lucencies seen in the right parietal bone with cortical thickening, which was also seen in the calvarium, mandible, mastoids, and sphenoid. Lumbar spine revealed Paget disease of L2 and L3, with coarse trabeculation of the T3 and T9 vertebral bodies. A bone scan revealed abnormal intense uptake in the calvarium, manubrium, left scapula, lower dorsal vertebral body, right pubic bone, and left distal femur consistent with Paget disease. At the age of $44 \mathrm{y}$, she received intravenous bisphosphonate for her PDB, which gave her temporary relief from the pain. She has also had an 8 y history of constant aching of the pectoral, shoulder, and thigh muscles. She is unable to raise her arms up and has difficulty climbing stairs. Physical evaluation reveals the typical weakness of the iliopsoas, quadriceps, and mild atrophy of the forearms bilaterally. She has a widebased gait. At $48 \mathrm{y}$, a muscle biopsy containing atrophic fibers revealed muscle with no pathologic diagnosis. An EMG showed small amplitude motor units in the biceps and vastus lateralis consistent with a myopathic process. She iscurrently on disability for her muscular dystrophy.

Case 4 is a 57 y old male currently on disability from PDB and LGMD. He is unable to raise his arms and walks slowly with the assistance of a cane. He has moderately severe pain in his thoracic and lumbar spine. He is a smoker and has respiratory difficulties. Skeletal $\mathrm{X}$-rays and bone scan reveals active PDB in the skull, shoulder, hip, and lumbar and vertebral spine. An echocardiogram was normal. Physical examination reveals tenderness of the spine and hip in addition to features of LGMD. Treatment includes bisphosphonates and calcitonin. An EMG showed small amplitude motor potentials in the leg muscles suggestive of a primary muscle disorder and focal abnormalities of upper extremity nerves. The NCV were normal.

Case 5, the 33-year-old son of case 4 , has had back and right hip pain for approximately 18 months. X-ray studies suggested PDB in the hip, skull, and spine. Examination revealed an individual who walked slowly with a limp because of back pain. He had moderately severe tenderness of the back over the thoracic and lumbar spine. Bone specific alkaline phosphatase and osteocalcin levels were markedly elevated. He is being treated with analgesics and calcitonin. He did not have evidence of muscular dystrophy clinically, and his CPK was normal.

Case 6 was evaluated after his death at age $50 \mathrm{y}$. Diagnosis of LGMD, PDB, and cardiomyopathy was at $38 \mathrm{y}$. He had a prior history of diabetes mellitus, stroke, obesity, and coronary artery disease for which he had a balloon angioplasty. Medical records indicate that his alkaline phosphatase levels were consistently elevated. Physical examination revealed left-sided hemiparesis from the stroke, shoulder and pelvic muscle atrophy. He had not received any prior treatment for Paget disease 

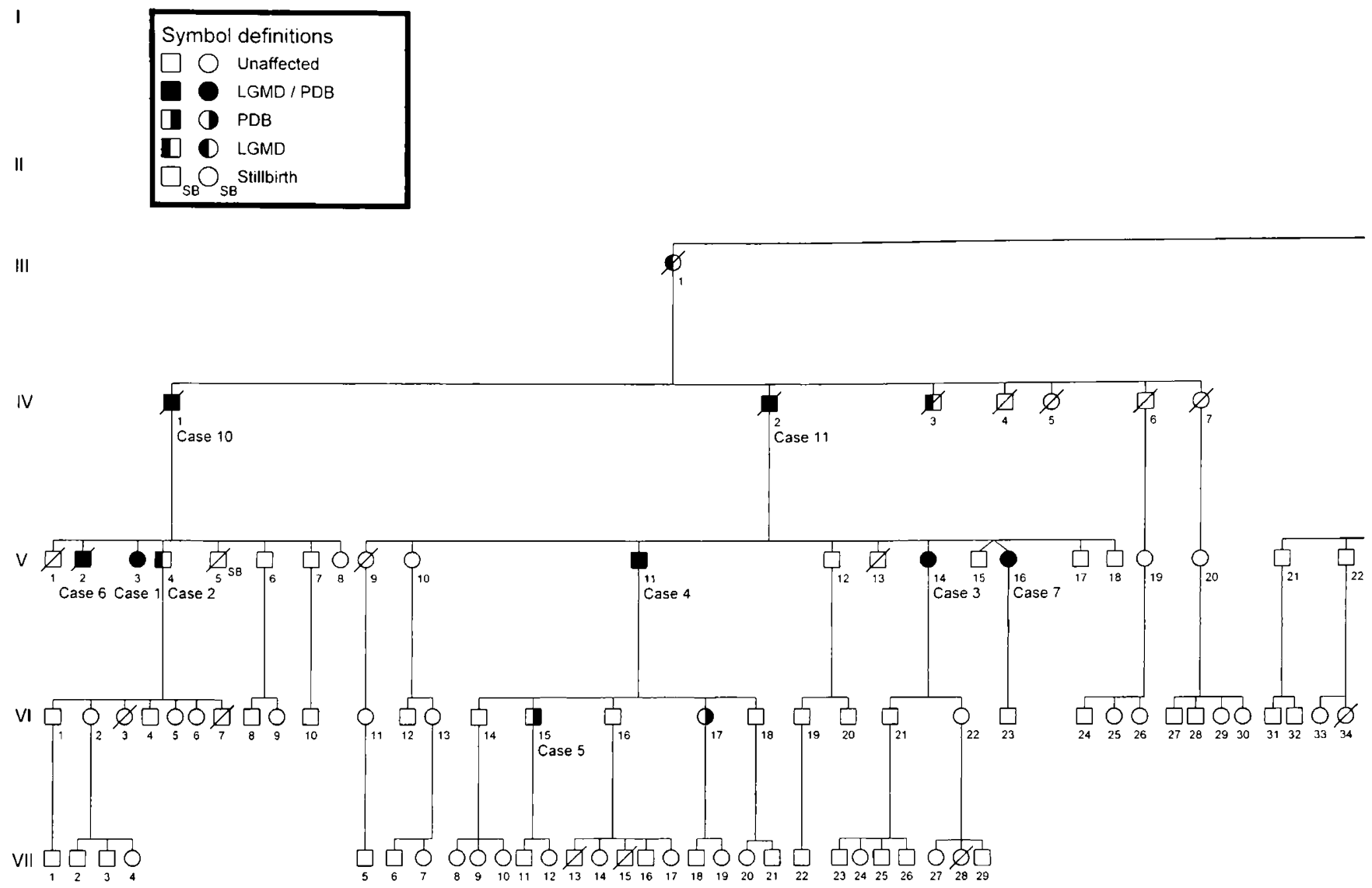

Fig. 1 Pedigree of family affected with autosomal dominant LGMD and PDB. Circles denote females, squares denote males, slashed symbols denote deceased individuals.

of bone. He had been bedridden for several months prior to death from cardiac failure.

Case 7, a 45 y female, was recently diagnosed with PDB because of back and shoulder pain. MRI of the back showed Paget disease in the L5 vertebral body. Total alkaline phosphatase levels were elevated. On examination, she had proximal muscle weakness of the arms and hips and wasting of the small muscles of the hands consistent with LGMD. She is currently receiving treatment with Fosamax (alendronate sodium), cyclobenzaprine, and analgesics.

Case 8 , age $46 y$, was diagnosed with LGMD at age $40 y$ when he noticed muscle weakness and atrophy of bilateral upper arms. He has weakness in his legs and upper arms and has difficulty getting up from a squatting position. Muscle biopsy reveals atrophic fibers and end stage myopathy. EMG shows mild spontaneous activity and small amplitude motor potentials consistent with a primary muscle disorder. Nerve conduction studies were normal. CPK levels were highly elevated and alkaline phosphatase levels were normal. X-rays did not reveal definite evidence of PDB. His father had a history of Paget disease, and died at $73 \mathrm{y}$ due to respiratory compromise related to LGMD.

Case 9 first noticed muscular weakness at age $50 \mathrm{y}$. The disease progressed to cause severe weakness of the muscles, making it difficult for him to get out of a chair. He was wheelchair bound for the last year and required supplemental $\mathrm{O}_{2}$. Additionally, he had peripheral neuropathy causing loss of sensation in his extremities. Deep tendon reflexes were absent in the leg. He reported no disability from PDB, which was discovered at $37 \mathrm{y}$, after a spine $\mathrm{x}$-ray was performed to investigate a fall from a ladder. A bone scan revealed intense activity in the right clavicle, L3 vertebra, right hemipelvis, sacrum, and left acetabulum. Laboratory results showed his total alkaline phosphatase was greatly elevated. His CPK was borderline elevated. His echocardiogram was grossly normal. A series of muscle biopsies in case 9 shows a progression of the disorder. At $40 \mathrm{y}$, there were minimal and nonspecific changes with occasional atrophic fibers favoring a "lower motor neuron disease" rather than muscular dystrophy. Aside from these minor variations, the biopsy was reported as within normal limits. At $55 \mathrm{y}$, degenerating and regenerating fibers, along with fiber size variation was noted. Small vacuolated fibers were also seen scattered throughout the muscle (Fig. 2). A final biopsy at $63 \mathrm{y}$ revealed severe, chronic myopathy with vacuolar changes, including rimmed vacuoles, and atrophic fibers in large groups of whole fascicles NCV studies suggested mild carpal tunnel syndrome. EMG showed mild myopathic changes. He died at age $65 \mathrm{y}$ from respiratory failure.

Cases 10 and 11 were not examined. Medical information was obtained from medical records. 


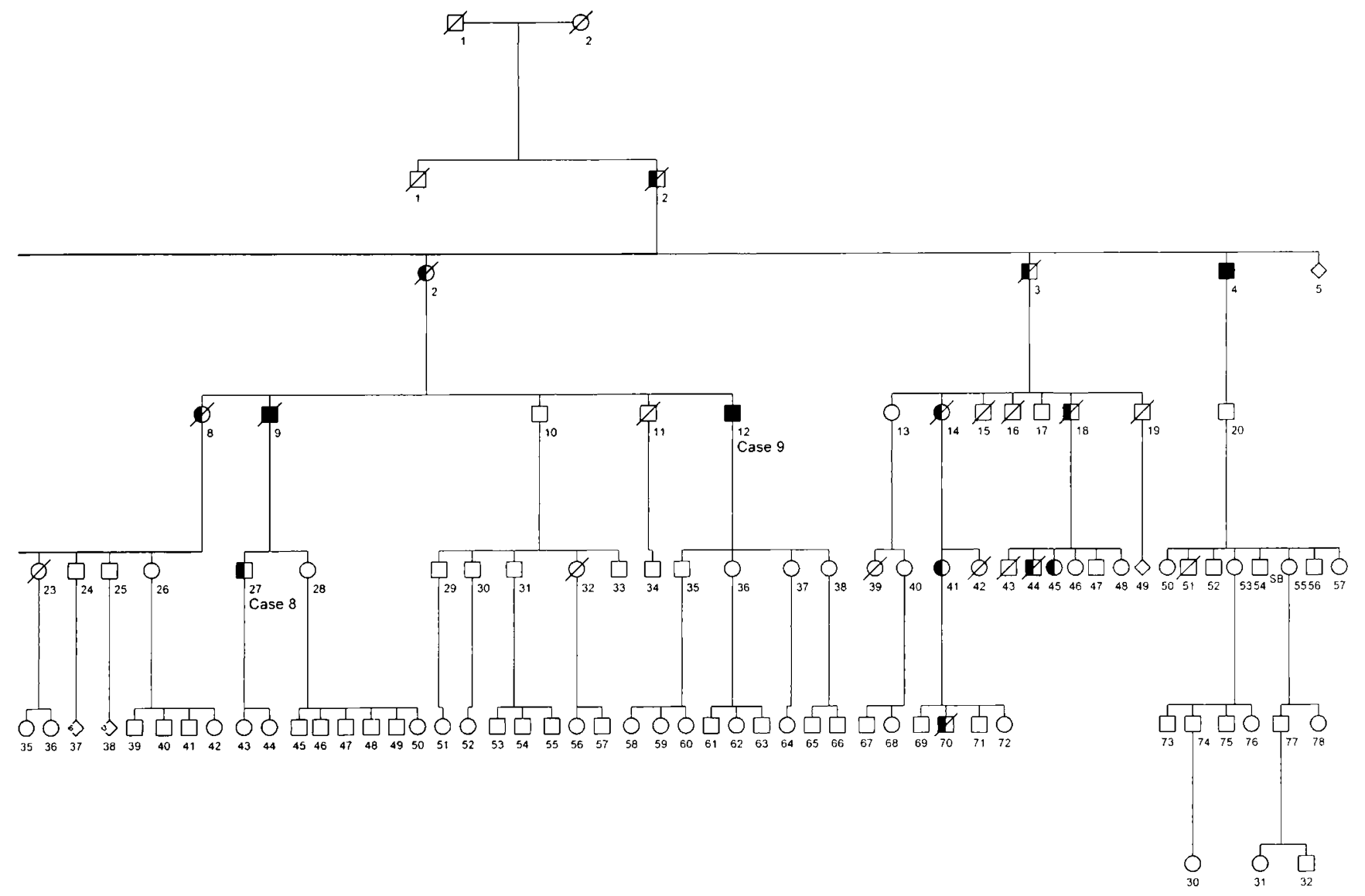

Fig. $1 b$.

Table 3

Clinical data of affected individuals ${ }^{*}$

\begin{tabular}{|c|c|c|c|c|c|c|c|c|}
\hline Case & Age $(y)$ & Sex & PDB & LGMD & $\begin{array}{l}\text { Age Dx } \\
\operatorname{PDB}(y)\end{array}$ & $\begin{array}{l}\text { Age Dx } \\
\text { LGMD } \\
(y)\end{array}$ & Treatment & Activity Level \\
\hline 1 & 48 & $\mathrm{~F}$ & + & + & 34 & 44 & None & $\begin{array}{l}\text { Difficulty going up stairs and raising arms, back/leg pain, } \\
\text { lumbar lordosis, wide based gait }\end{array}$ \\
\hline 2 & 47 & M & - & + & - & 45 & None & Weakness in proximal arm and leg muscles \\
\hline 3 & 49 & $\mathrm{~F}$ & + & + & 44 & 48 & $\begin{array}{l}\text { Previous } \\
\quad \text { bisphosphonates }\end{array}$ & $\begin{array}{l}\text { Difficulty climbing stairs, lifting arms, extremity atrophy } \\
\text { of extremities, lordotic posture, waddling gait }\end{array}$ \\
\hline 4 & 57 & M & + & + & 42 & 54 & $\begin{array}{l}\text { Calcitonin and } \\
\text { bisphosphonates }\end{array}$ & $\begin{array}{l}\text { Walks slowly with cane, severe pain and tenderness in } \\
\text { spine and hip }\end{array}$ \\
\hline 5 & 33 & M & + & - & 31 & - & $\begin{array}{l}\text { Analgesics and } \\
\text { calcitonin }\end{array}$ & Walks slowly with a limp, tenderness in back, pain in hip \\
\hline 6 & 50 & M & + & + & 38 & 38 & None & $\begin{array}{l}\text { Bedridden for several months, left side hemiparesis from } \\
\text { stroke }\end{array}$ \\
\hline 7 & 47 & $\mathrm{~F}$ & + & + & 45 & 45 & $\begin{array}{l}\text { Alendronate, } \\
\text { cyclobenzaprine }\end{array}$ & $\begin{array}{l}\text { Difficulty sitting, getting up from chair, back pain and } \\
\text { weakness of the arms and hips }\end{array}$ \\
\hline 8 & 46 & M & - & + & - & 40 & None & Unable to run, difficulty with stairs \\
\hline 9 & 64 & M & + & + & 37 & 40 & None & Wheelchair bound, loss of sensation in extremities \\
\hline 10 & 59 & M & + & + & UK & 51 & None & $\begin{array}{l}\text { Bedridden } 3 \text { y prior to death, winging of the scapulae, } \\
\text { weakness of trunk \& lower extremities }\end{array}$ \\
\hline 11 & 61 & M & + & + & 61 & UK & None & Difficulty walking, pain in spine and pelvis and femur \\
\hline MEAN & 50.9 & $3 \mathrm{~F} / 8 \mathrm{M}$ & 9 & 10 & 41.5 & 45.6 & & \\
\hline
\end{tabular}

*+ = present; - = absent; UK = unknown. 
Table 4

Laboratory data of affected individuals*

\begin{tabular}{|c|c|c|c|c|c|c|c|}
\hline Case & $\begin{array}{c}\text { Alkaline } \\
\text { Phosphatase } \\
\text { (30-130 IU/L) }\end{array}$ & $\begin{array}{l}\text { Bone Specific } \\
\text { Alkaline } \\
\text { Phosphatase } \\
\text { (39-151 IU/L) }\end{array}$ & $\begin{array}{l}\text { Osteocalcin } \\
(8.0-52.0 \\
\mathrm{ng} / \mathrm{mL})\end{array}$ & $\begin{array}{c}\text { CPK } \\
(20.0-222.0 \\
\mathrm{U} / \mathrm{L})\end{array}$ & $\begin{array}{l}\text { Muscle Biopsy } \\
\text { Findings }\end{array}$ & $\begin{array}{l}\text { Echocardiogram } \\
\text { Findings }\end{array}$ & $\begin{array}{l}\text { X-ray Findings } \\
\text { of Paget }\end{array}$ \\
\hline 1 & 1137 & 1133 & 34.4 & 60 & NT & Normal & $\mathrm{L} 1, \mathrm{~L} 2, \mathrm{~L} 3$, and pelvis \\
\hline 2 & 93 & NT & 25.2 & 220 & $\begin{array}{l}\text { Fiber size variation, } \\
\text { splitting \& nesting }\end{array}$ & Cardiomyopathy & No Paget \\
\hline 3 & 354 & 351 & 19.1 & 98 & Atrophic fibers & NT & $\mathrm{L} 2, \mathrm{~L} 3$, and pubic bone \\
\hline 4 & 786 & 764 & 5 & 268 & Myopathy & Normal & Spine, hip, and skull \\
\hline 5 & 1724 & 1724 & 54.6 & 90 & NT & NT & Spine, hip, and skull \\
\hline 6 & 240 & NT & NT & 82 & NT & Cardiomyopathy & NT \\
\hline 7 & 329 & NT & NT & NT & NT & NT & L5 \\
\hline 8 & 88 & 85 & 1 & 1145 & End stage myopathy & Normal & Possible early Paget \\
\hline 9 & 1508 & 1488 & 1 & 220 & $\begin{array}{l}\text { Muscle atrophy, } \\
\text { vacuolar } \\
\text { myopathy }\end{array}$ & $\begin{array}{l}\text { Aortic valve } \\
\text { calification, mild } \\
\text { cardiomyopathy }\end{array}$ & Widespread \\
\hline 10 & 431 & NT & NT & 84 & $\begin{array}{l}\text { Adipose tissue } \\
\text { between muscle } \\
\text { bundles }\end{array}$ & NT & NT \\
\hline 11 & 1535 & NT & NT & NT & NT & Normal & $\begin{array}{l}\text { Lumbar spine and } \\
\text { pelvis }\end{array}$ \\
\hline Mean & 747.7 & 924.2 & 20.0 & 251.9 & & & \\
\hline
\end{tabular}

${ }^{*} \mathrm{NT}$, not tested; CPK, creatine phosphokinase.

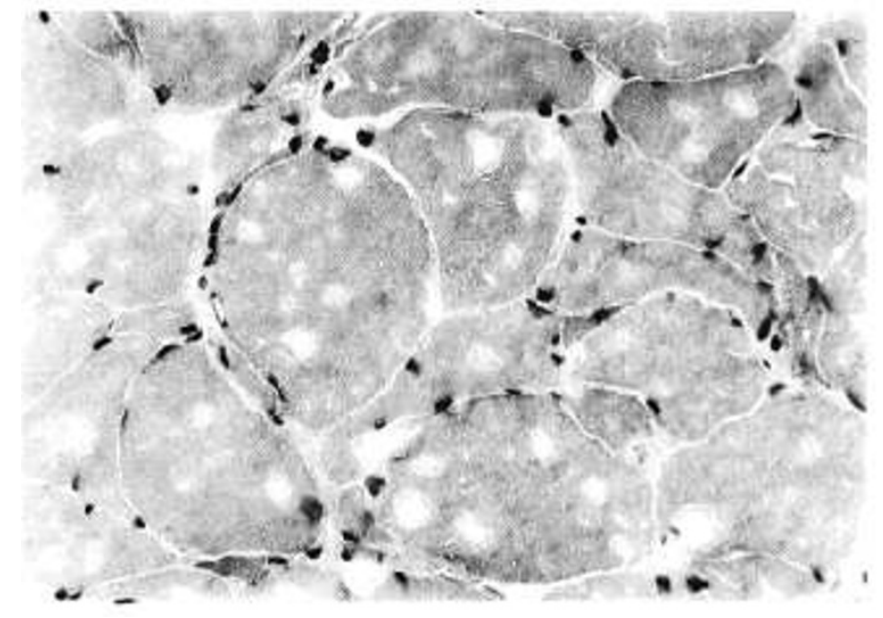

Fig. 2 High powered magnification (hematoxylin and eosin, $\times 400$ ) of muscle from the right deltoid of case 9 showed variation in fiber size with frequent angular fibers. Many of the fibers contained blue, rimmed vacuoles.

Case 10 died at the age of $59 \mathrm{y}$ after being bedridden for the preceding three years. Symptoms of the LGMD began with progressive weakness of both his upper and lower extremities at $51 \mathrm{y}$. He had difficulty walking up the stairs and experienced aching and weakness of his trunk muscles and lower extremities, which affected the thighs more than the lower legs. He demonstrated winging of the scapulae bilaterally. Alkaline phosphatase levels were elevated, while CPK levels were within the normal range. A muscle biopsy was performed and adipose tissue was seen between some of the muscle bundles with no specific findings of intrinsic muscle disease.

Case 11 died at age 61 y of congestive heart failure and PDB. He had a history of diabetes mellitus, pulmonary obstructive disease, chronic bronchitis and bronchial asthma, and Paget disease involving the lumbar spine, pelvis, and proximal portions of both femurs. His alkaline phosphatase levels were greatly elevated. He demonstrated winging of the scapulae and weakness in the arms. He also experienced intermittent hypertension and mild coronary insufficiency. His EKG showed slight ST depression in V5 and V6 and his alkaline phosphatase levels were greatly elevated.

\section{Laboratory evaluation}

Paget disease of bone

All individuals showing radiologic evidence of PDB had corresponding elevated alkaline phosphatase levels (Table 4). The mean value of total alkaline phosphatase in affected individuals was $747.7 \mathrm{IU} /$ liter (normal range 30-130 U/liter) with a range of 88-1724 IU/liter. Cases 2 and 8 were not clinically diagnosed with PDB and had normal alkaline phosphatase levels. Osteocalcin was elevated only in the youngest individual, $33 \mathrm{y}$, to a value of $54.6 \mathrm{ng} / \mathrm{mL}$ (normal range $8-52 \mathrm{ng} / \mathrm{mL}$ ). All other individuals had normal levels with a mean of $20.0 \mathrm{ng} / \mathrm{mL}$. Additionally, urine pyridolinium cross link studies were obtained in all individuals, but results were not helpful in distinguishing affected from unaffected individuals (data not shown). 
Table 5

Clinical, radiological and biochemical data in Paget and neuromuscular disease (NMD) reported in the literature

\begin{tabular}{|c|c|c|c|c|c|c|c|c|}
\hline Author & Case & Sex & PBD & NMD & $\begin{array}{c}\text { Alkaline Phosphatase } \\
\text { (4.5-13 KA units, } \\
30-115 \mathrm{U} / \mathrm{L}) \\
\end{array}$ & $\begin{array}{l}\mathrm{CPK}(0-100 \\
\mathrm{U} / \mathrm{L})\end{array}$ & $\begin{array}{l}\text { Paget Disease } \\
\text { Involvement }\end{array}$ & Neuromuscular Disease \\
\hline \multirow[t]{5}{*}{ McBride et. $\mathrm{al}^{2}$} & 1 & M & + & + & $161 \mathrm{KA}$ units & Normal & Widespread & $\begin{array}{l}\text { Onset at } 33 \text { y, proximal muscle weakness, muscle } \\
\text { biopsy consistent with LGMD }\end{array}$ \\
\hline & 2 & M & + & + & $154 \mathrm{KA}$ units & Normal & $\begin{array}{l}\text { Lumbar } \\
\text { spine, } \\
\text { pelvis, } \\
\text { upper } \\
\text { femora, left } \\
\text { tibia }\end{array}$ & $\begin{array}{l}\text { Myocardial ischaemia. EMG showed myophathi } \\
\text { pattern, weakness and wasting of shoulder } \\
\text { girde and pelvis, hands severely affected }\end{array}$ \\
\hline & 3 & M & + & + & $23 \mathrm{KA}$ units & Normal & Lumbar spine & $\begin{array}{l}\text { Deterioration of mental condition, wasting of } \\
\text { upper limb muscles, thighs, and hands }\end{array}$ \\
\hline & 4 & $\mathrm{~F}$ & + & + & $27 \mathrm{KA}$ units & Normal & Widespread & $\begin{array}{l}\text { Scoliosis, scapular winging, wasting of hand } \\
\text { muscles, waddling gait }\end{array}$ \\
\hline & 5 & $\mathrm{~F}$ & + & - & 14.8 KA units & Normal & $\begin{array}{l}\text { Single lumbar } \\
\text { vertebra }\end{array}$ & $\begin{array}{l}\text { Diagnosed with schizophrenia, no muscle } \\
\text { weakness or wasting }\end{array}$ \\
\hline \multirow[t]{3}{*}{ Caughey et. al ' } & 1 & M & + & + & $68 \mathrm{KA}$ units & NA & $\begin{array}{l}\text { Pelvis, spine } \\
\text { and skull }\end{array}$ & $\begin{array}{l}\text { Myotonic dystrophy features; baldness at } 17 \mathrm{y} \\
\text { stiff leg muscles, bilateral cataracts, myotonia } \\
\text { of the tongue, weak abdominal muscles }\end{array}$ \\
\hline & 2 & M & + & + & NA & NA & $\begin{array}{l}\text { Spine and } \\
\text { pelvis }\end{array}$ & $\begin{array}{l}\text { Weakness of neck flexors and abdomen, } \\
\text { myotonia of hands and tongue, frontal } \\
\text { baldness, leukoderma of face and limbs }\end{array}$ \\
\hline & 3 & M & - & + & $\mathrm{NA}$ & NA & $\begin{array}{l}\text { No evidence } \\
\text { of Paget }\end{array}$ & $\begin{array}{l}\text { Myotonia of the hands, hypertrophy of the thigh } \\
\text { and calf muscles, muscle size disproportionate } \\
\text { to strength }\end{array}$ \\
\hline${\text { Tucker et. } \mathrm{al}^{3}}^{3}$ & 1 & M & + & + & $222 \mathrm{U} / \mathrm{L}$ & $125 \mathrm{U} / \mathrm{L}$ & $\begin{array}{l}\text { Pelvic, L5, } \\
\text { femoral } \\
\text { heads, skull }\end{array}$ & $\begin{array}{l}\text { Amyotropic lateral sclerosis, moderate atrophy } \\
\text { of limb girdle muscles, winging of scapulae, } \\
\text { waddling gait, absent tendon reflexes, onset at } \\
40 \mathrm{y}\end{array}$ \\
\hline
\end{tabular}

$\mathrm{NA}=$ not available.

Limb-girdle muscular dystrophy

All individuals diagnosed with LGMD were characterized by severe muscle weakness particularly in the arms, legs, shoulder, and pelvic girdle. Laboratory evaluations of the CPK were not found helpful in screening for LGMD in the majority of individuals. Only $2 / 11$ individuals had elevations of CPK (normal, $60-222$ IU/liter).

\section{Muscle biopsy}

Six out of eleven individuals had muscle biopsies. Histology in 5 individuals showed nonspecific myopathic changes (Table 4). A series of muscle biopsies in case 9 shows a progression of the disorder. At age $40 \mathrm{y}$, the muscle was almost normal. At $55 \mathrm{y}$, generating and regenerating fibers were present with fiber size variation and small vacuolated fibers (Fig. 2). At age $63 \mathrm{y}$, he had severe, chronic myopathy with vacuolar changes, rimmed vacuoles, and atrophic fibers in large groups of whole fascicles.

\section{Electromyographic (EMG) studies}

EMG was performed on 5 affected individuals. Overall, the studies revealed spontaneous fibrillation, small polyphasic motor units and mild membrane irritability consistent with a myopathic process as seen in LGMD. One individual (case 9) had additional neuropathic changes clinically and on EMG.

\section{Linkage analysis}

Linkage analysis was carried out on 23 members of the family ( 9 affected, 13 unaffected, 1 spouse) with molecular markers for established loci of autosomal dominant LGMD and autosomal dominant PDB. Linkage to the autosomal recessive forms of LGMD as well as 6 loci for dominant cardiomyopathy was also examined for this pedigree. Sufficiently negative LOD scores were obtained for all markers evaluated (Table 2), thus excluding all the candidate genes from linkage.

\section{DISCUSSION}

Limb-girdle muscular dystrophy associated with Paget disease is an unusual disorder. Paget disease of bone affects approximately $2-3 \%$ of the population $>50 \mathrm{y}$, and autosomal dominant LGMD is extremely rare; therefore, the co-occurrence of both disorders by chance in $8 / 11$ individuals in our family is unlikely. ${ }^{23}$

Three reports of families with Paget disease of bone and neuromuscular disease have been described previously (Table 
5). $\mathrm{McBride}^{3}$ reported a family of 6 siblings: three brothers and one sister were diagnosed with widespread Paget disease of bone and muscular dystrophy, one sister had localized Paget disease in one lumbar vertebra, and one brother was unaffected. Possible mild phenotype in the mother was reported so the inheritance pattern was difficult to deduce.

Caughey et al. ${ }^{1}$ reported three brothers with dytrophia myotonica, two of whom had PDB. Individuals had typical features of dystrophia myotonica including stiff muscles, inability to relax the grip, myotonia of the tongue and hand muscles, hypertrophy of the biceps and forearms, muscle size disproportionate muscle strength, and weakness of the abdominal and sternomastoid muscles. One of the brothers exhibiting Paget of the vertebrae and pelvis had a neoplastic process compressing the spinal cord. The parents were unaffected, possibly suggesting autosomal recessive inheritance.

Tucker et al. ${ }^{4}$ described a family with lower motor neuron degeneration and "Paget-like bone disease." In the nine individuals pelvic and shoulder muscle weakness and atrophy started at 35-40y, with death occurring before the age of $60 \mathrm{y}$. Of the nine individuals, seven were known to exhibit signs of Paget disease. The reported features were very similar to our family; however, there was no instance of male-to-male transmission in the family possibly suggesting an X-linked mode of inheritance. An isolated case report of 53 y old male with PDB and lower motor neuron was reported by Varelas and Kapati ${ }^{24}$ who estimated that the combined incidence of PDB and ALS ranges between 0.012 and $0.108 / 100,000$.

Cardiac failure and cardiomyopathy occurs in the latter stages of the disease in some individuals in our family. Two of these individuals are heavy smokers and have coronary artery disease; therefore, the significance of cardiomyopathy is uncertain in them. Messina et al. ${ }^{13}$ reported a four-generation family with conduction defect (CDCD3) and muscle weakness, which they mapped to 6q23. Van der Kooi et al. ${ }^{10}$ identified a family demonstrating LGMD1B with related cardiac abnormalities in $62.5 \%$ of the affected individuals and sudden cardiac death at approximately $50 \mathrm{y}$. Paget disease of bone has been known to lead to high output congestive heart failure due to the increased vascularity of abnormal bone. ${ }^{25}$ Linkage analysis was undertaken for candidate loci for cardiomyopathy; however, they were excluded.

Pharmacological treatment of PDB has included calcitonin, a peptide hormone that inhibits osteoclast activity. Bisphosphonates, are more successful in the management of Paget disease, induce marked and prolonged inhibition of bone resorption through a direct effect on mature osteoclasts. Disruption of cellular metabolism and induction of osteoclast apoptosis are the most likely mechanisms. ${ }^{26}$ Etidronate was the first bisphosphonate to be used in the management of Paget disease. ${ }^{27}$ Introduction of additional bisphosphonates include pamidronate, tiludronate, alendronate, and risedronate, respectively, with each increasing in potency and efficacy.

Therapy in the muscular dystrophies has been less successful and has included coenzyme $\mathrm{Q},{ }^{28}$ steroids, ${ }^{29}$ myoblast transfer ${ }^{30}$ and gene therapy clinical trials in the autosomal recessive types of LGMD. ${ }^{31-32}$

In conclusion, the results from our linkage analysis confirm that autosomal dominant LGMD with associated PDB is genetically distinct. Discovery of new genes involved in dominant LGMD should provide insight into the pathogenesis of muscle disease as they have done in the autosomal recessive types. ${ }^{33}$ It is possible that a biochemical overlap exists between the biological processes of bone and muscle maintenance and regeneration that could potentially be influenced by a single gene mutation. Elucidation of the gene responsible for LGMD associated with PDB may help unravel the biochemical nature of this unique disorder, eventually resulting in the development of novel treatment protocols including gene therapy.

\section{Acknowledgments}

This research has been funded by a grant from the Central Research Committee and Excellence in Academic Medicine Award from Southern Illinois University and the Muscular Dystrophy Association.

We thank the members of the family for their participation in our study; Dr. Gregory Gregg, Radiology, St. Johns Hospital, for interpretation of $\mathrm{x}$-rays; Dr. Jhaveri, Dr. Onsi Kamel, and Rod Angeli, Pathology Department, St. John's Hospital, for assistance with laboratory results; Dr. Stephen Jennison and Claire Call, Prairie Heart Institute; Shawnia Forrester, Division of Genetics, Southern Illinois University; and Katerina Kimonis from Springfield, IL; Dr. Marzia Pasquale, Emory University, Atlanta, GA; Dr. Michael Whyte, Metabolic Research Unit, Shriners Hospital for Children, St. Louis, MO; and Beverly McElroy, RN, NINDS, National Institutes of Health, Bethesda, MD, for their contributions.

\section{References}

1. Caughey JE, Gwynne IF, Jefferson NR. Dystrophia myotonica associated with familial Paget's disease (osteitis deformans) with sarcomata. J Bone Joint Surg Br 1957;39: 316-325.

2. MIM (Online Mendelian inheritance in man) Baltimore: Johns Hopkins University, Center for Medical Genetics, 2000. Available at: http://www3.ncbi.nlm.nih.gov/ omim/

3. McBride TI. Paget's disease and muscular dystrophy: report of an unusual association in one family. Scott Med J 1966;11:238-243.

4. Tucker WS Jr, Hubbard WH, Stryker TD, Morgan SW, Evans OB, Freemon F, Theil GB. A new familial disorder of combined lower motor neuron degeneration and skeletal isorganization. Trans Assoc Am Phys 1982;95:126-134.

5. Hauser MA, Salmikangas $\mathrm{P}$, Horrigan $\mathrm{SK}$, Viles KD, Torian UM, Taivainen $\mathrm{L}$, et al Positional cloning of the gene responsible for limb-girdle muscular dystrophy $1 \mathrm{~A}$. Am J Hum Genet 1999;65:574A.

6. Speer MC, Y amaoka LH, Gilchrist IH, Gaskell CP, Stajich IM, Vance JM, Kazantsev A, Lastra AA, Haynes CS, Beckman IS, et al. Confirmation of genetic heterogeneity in limb-girdle muscular dystrophy: linkage of an autosomal dominant form to chromosome 5q. Am J Hum Genet 1992;50:1211-1217.

7. Bartoloni L, Horrigan SK, Viles KD, Gilchrist JM, Stajich JM, Vance JM, Yamaoko LH, Pericak-Vance MA, Westbrook CA, Speer MC. Use of a CEPH meiotic breakpoint panel to refine the locus of limb-girdle muscular dystrophy type IA (LGMDIA) to a 2-Mb interval on 5q31. Genomics 1998:54:250-255.

8. Minetti C, Sotgia F, Bruno C, Scartezzini P, Broda P, Bado M, Masetti E, Mazzocco M, Egeo A, Donati MA, Volonte D, Galbiati F, Cordone G, Bricarelli FD, Lisanti MP, Zara F. Mutations in the Caveolin-3 gene cause autosomal dominant limb-girdle muscular dystrophy. Nat Genet 1998;18:365-368.

9. Song KS, Scherer PE, Tang Z, Okamoto T, Li S, Chafel M, Chu C, Kohty DS, Lisanti MP. Expression of caveolin-3 in skeletal, cardiac, and smooth muscle cells: caveolin-3 is a component of the sarcolemma and co-fractionates with dystrophin and 
dystrophin-associated glycoproteins. / Biol Chem 1996;271:15160-15165

10. Van der Kooi AJ, van Meegen M, Ledderhof TM, McNally EM, de Visser M, Bolhuis PA. Genetic localization of a newly recognized autosomal dominant limb-girdle muscular dystrophy with cardiac involvement (LGMD 1 B) to chromosome lq1 1-21. Am J Hum Genet 1997;60:891-895.

11. Speer MC, Vance IM, Grubber IM, Lennon Graham F, Stajich IM, Viles KD, Rogala A, McMichael R, Chutkow J, Goldsmith C, Tim RW, Pericak-Vance MA. Identification of a new autosomal dominant limb-girdle muscular dystrophy locus on chromosome 7. Am J Hum Genet 1999;64:556-562.

12. Nicolao P, Xiang F, Gunnarsson LG, Giometto B, Edstrom L, Anvret M, Zhang Z Autosomal dominant myopathy with proximal weakness and early respiratory muscle involvement maps to chromosome 2q. Am / Hum Genet 1999;64:788-792.

13. Messina DN, Speer MC, Pericak-Vance MA, MiNally EM. Linkage of familial di lated cardiomyopathy with conduction defect and muscular dystrophy to chromosome 6q23. Am J Hum Genet 1997;61:909-917.

14. Delmas PD, Meunier PI. The management of Paget disease of bone. $N$ Engl J Med 1997;336:558 -566.

15. McKusick VA. Paget's disease of the bone. In: Heritable disorders of connective tissue, 3rd Ed. St. Louis: C.V. Mosby, 1960:718-723.

16. Fotino M, Haymivits A, Falk CT. Evidence for linkage between HLA and Paget's disease. Transplant Proc 1977;9:1876-1868.

17. Cody JD, Singer FR. Genetic linkage of Paget's disease of the bone to chromosome 18q. Am J Hum Genet 1997;61:1117-1122.

18. Hughes $A E$, Ralston $\mathrm{SH}$, Marken I, Bell C, MacPherson $\mathrm{H}$, Wallace RGH, van Hu W, Whyte MP, Nakatsuka K, Hovy L, Anderson DM. Mutations in TNFRSF11A. affecting the signal peptide of RANK, cause familial expansile osteolysis. Niat Genet $2000 ; 24: 45-48$.

19. van Hul W. Paget's disease from a genetic perspective. Bone 1999:24(Suppl 5):29-

20. Ott J. Computer-simulation methods in human linkage analysis. Proc Natl Acad Sc US A 1989;86:4175-4178.

21. Weeks DE, Ott I, Lathrop GM. Slink: a general simulation program for linkage analysis. Am J Hum Genet 1994;47(Suppl):A204.

22. Cottingham RW Jr, Idury RM, Schaffer AA. Faster sequential genetic linkage computations. Am J Hum Genet 1993;53:252-263.

23. Schmorl G. Ueber Ostitis deformans Paget. Virchow's Arch Pathol Anat Phy'siol Klin Med 1932:238:694-751.

24. Varelas PN, Bertoni TE, Kapaki E, Papagerogiou CT. Paget's disease of bone and motor neuron disease. Muscle Nerve 1997;5:630.

25. Hultgren HN. Osteitis deformans (Paget's disease) and calcific disease of the heart valves. A m J Cardiol 1998;81:1461-1464.

26. Hughes DE, Wright KR, Ly HL. Bisphosphonatases promote apoptosis in murine osteoclasts in vitro and in vivo. J Bone Miner Res 1995;10:1478-1 487.

27. Smith R, Russell RG, Bishop M, Woods C, Bishop M. Paget's disease of boneexperience with diphosphonate in treatment. Q J Med 1973;42:235-238.

28. Folkers $\mathrm{K}$, Wolaniuk J, Simonsen R, Morishita M. Biochemical rationale and the cardiac response of patients with muscle disease to therapy with coenzyme Q. Proc Natl Acad Sci U S A 1985;82:901-904.

29. Dubrovsky AL, Angelini C, Bonifati DM, Pegoraro E, Mesa L. Steroids in muscular dystrophy: where do we stand? Neuromuscul Disord 1998;8:380-384
30. Mendell JR, Kissel IT, Amato AA, King W, Signore L, Prior TW, Sahenk Z, Benson S, McAndrew PE, Rice R. Myoblast transfer in the treatment of Duchenne muscular dystrophy. N Engl J Med 1995;333:832-838.

31. Karpati G, Pari G, Molnar MI. Molecular therapy for genetic muscle disease-status 1999. Clin Genet 1999;55:1-8

32. Muscular Dystrophy Association, New York, New York. 2000. http://www.mdausa. org/research.

33. Bushby K. Making sense of the limb-girdle muscular dystrophies. Brain 1999;122: 1403-1420.

34. Beckmann JS, Richard I, Hillaire D, Broux O, Antignac C. Bois E, Cann H, Cottingham RW Ir. Feingold N, Feingold J, et al. A gene for limb-girdle muscular dystrophy maps to chromosome 15 by linkage. CR Acad Sci III 1991;312:141-148.

35. Richard I, Broux O, Allamand V, Fougerousse F, Chiannilkulchai N, Bourg N, Brenguier L, Devaud C, Pasturand P, Roudent $C$, et al. Mutations in the proteolytic enzyme calpain 3 cause limb-girdle muscular dystrophy type 2A. Cell 1995;81:2740.

36. Bashir R, Strachan T, Keers S, Stephenson A, Mahineh I, Marconi G, Nashef L, Bushby KM. A gene for autosomal recessive limb-girdle muscular dystrophy maps to chromosome 2p. Hum Mol Genet 1994;3:455-457.

37. Noguchi S, McNally EM, Ben Othmane K, Hagiwara Y, Mizuno Y, Yoshida M, Yamamoto $\mathrm{H}$, Bonnemann CG, Gussoni $\mathrm{E}$, Denton $\mathrm{OH}$, et al. Mutations in the dystrophin-associated protein gamma-sarcoglycan in chromosome 13 muscular dystrophy. Science 1995;270:819-821.

38. Roberds SL, Leturcq F, Allamand V, Piccolo F, leanpierre M, Anderson RD, Lim LE, Lee IC, Tome FM, Romeo NB, et al. Missense mutations in the adhalin gene linked to autosomal recessive muscular dystrophy. Cell 1994;78:625-633.

39. Lim LE, Duclos F, Broux O, Bourg N, Sunada Y, Allamand V, Meyer J, Richard I, Noomaw C, Slaughter $C$, et al. Beta-sarcoglycan: characterization and role in limbgirdle muscular dystrophy linked to 4q12. Nat Genet 1995;11:257-265.

40. Nigro V, Moreira ES, Piluso G, Vainzof M, Belsito A, Politano L, Puca AA, PassosBueno MR, Zatz M. Autosomal recessive limb-girdle muscular dystrophy, LGMD2F, is caused by a mutation in the delta sarcoglycan gene. Nat Genet 1996;14: 195-198

41. Passos-Bueno MR, Moreira ES, Vainzof M, Marie SK, Zatz M. Linkage analysis in autosomal recessive limb-girdle muscular dystrophy (AR LGMD) maps a sixth form to 5q33-34 (LGMD2F) and indicates that there is at least one more subtype of AR LGMD. Hum Mol Genet 1996;5:815-820.

42. Moreira ES, Passos-Bueno MR, Wiltshire TI, Faulkner G, Nilforoushan A, Vainzof M, Suzuki OT, Valle G, Reeves R, Zatz M, Paaos-Bueno MK, Jenne DE. Limb-girdle muscular dystrophy Type $2 \mathrm{G}$ is caused by mutations in the gene encoding the sarcomeric protein telethonin. Nat Genet 2000;24:163-166.

43. Moreira ES, Vainzof M, Marie SK, Sertie AL, Zatz M, Passos-Bueno MR. The seventh form of autosomal recessive limb-girdle muscular dystrophy is mapped to 17q11-12. Am J Hum Genet 1997;61:151-159.

44. Weiler T, Greenberg CR, Zelinski T, Nylen E, Coghlan G, Crumley MI, Fuijwara TM, Morgan K, Wrogemann K. A gene for autosomal recessive limb-girdle muscular dystrophy in Manitoba Hutterites maps to chromosome region 9q31-q33: evidence for another limb-girdle muscular dystrophy locus. Am / Hum Genet 1998;63: $140-147$ 